Ethiopian Journal of Environmental Studies \& Management 7(1): 50 - 58, 2014

ISSN:1998-0507

doi: http://dx.doi.org/10.4314/ejesm.v7i1.6

Submitted: October 18, 2013

Accepted: January 20, 2014

\title{
SOCIO-ECONOMIC ANALYSIS OF DAILY LABOURERS IN URBAN MASSES: A CASE STUDY OF NORTHERN ETHIOPIA
}

MUSHIR ALI

Department of Geography and Environmental Studies, Mekelle University, Ethiopia, PB.451, Corresponding email: mushirjbd@gmail.com

\begin{abstract}
Present work is an attempt to analysis the socio-economic conditions of daily labourers, who play significant role through performing hard physical labour in growing Ethiopia cities. This study was conducted in Mekelle city with the objectives to assess ethnicity, religion, education and marital status of daily construction labourers, and to describe their income, residential, basic amenities and facilities. To fulfill the objectives, primary data were generated through field surveys. On the basic of purposive sampling 120 daily labourers were interviewed randomly from three selected sub-cities. The study analyses that $78 \%$ daily labourers belonged to Tigrian ethnicity who were mainly followers of Orthodox Christianity (66.7\%). The Migrant daily labourers were $83 \%$ whose educational background was measurable. Nearly $60 \%$ daily labourers were either illiterate or having only knowledge of read and write without any formal education. They survived lives engaging their family in poor employments consisted with hotel/restaurant workers (33.48\%) followed by agricultural labourers (27.23\%), housemaids (22.32\%) and pity sellers (16.96\%). The total family earning of $72.5 \%$ daily labourers was less than1200birr per month, and at least $76 \%$ their dwellings were starved of civil amenities and facilities.
\end{abstract}

Key words: Daily labour, society religion, ethnicity, occupation, income and urban area.

\section{Introduction}

Ethiopia has been growing economically fast at the turn of the century. Its economy has grown by an unprecedented $11 \%$ on average-up from less than $3 \%$ annual growth during the previous seven years, and much faster than average annual growth in Africa as a whole nearly 6\% (Brixiova, 2010). The services have made a record by seven percentage points over the period between 2003/04 and 2008/09 accounting nearly half of GDP growth since 2004. Per capita income of Ethiopians has more than doubled over the same period, though from a very low base, it was still below $\$ 400$ as of 2010. According to the Economists, Ethiopia is forecast to be the thirdfastest growing country in the world over the next five years, after China and India (Peter and Lamin, 2010; EEA, 2003).

Although Ethiopian economy remains heavily dependent on agriculture, the contribution of services has been increased (CSA, 2006). The share agricultural sector in GDP has been declined by three percentage points that has now been surpassed by services. Despite this impressive growth in services driven by the rapid expansion in financial intermediation, public administration, retail business activities, and the services for construction, the services of daily construction labourers have not been recognized (Ali, 2013).

These daily workers play a significance role in the construction industry. They assemble at street corners of the cities and towns in form of labour markets (Woolcock, 1998; Satterthwaite, 2004). Such type of markets is common on Ethiopian urban land where jobless, illiterate; in many cases educated workers assemble to get work for the earning their livelihood (Dessalegn and Aklilum, 2003). They work hard for the construction by carrying, loading unloading material on their heads and back at whole day to get earning for their survival (Chen and Lund, 2001). Majority of them involve form teen age and continued to be old age. However, the faulty planning and implementation regarding unemployment, poverty, high growth of population and price hike, which force to unemployed youth to adapt such type of 
works (Lewis, 1954; National Research Council, 2003). However, many works were accomplished on urban planning, architecture, traffic, formal and informal occupations but no study was conducted properly by sociologists, economists, geographers, planners and policymakers regarding the socioeconomic conditions of daily construction labourers; how is their living, their travelling behavior and educational status, how much they earn, where they reside, which type of basic amenities and facilities they avail and so on (Bitran, 2005; Sverdlik, 2011).

\section{Objectives}

Keeping the view importance of socioeconomic conditions of daily informal construction labourers, the work was conducted in Mekelle city with following objectives:

To assess the ethnicity, religion, education and marital status of daily construction labourers, and To describe their occupational structure, income, dwelling, basic amenities and facilities.

\section{Study Area}

Mekelle is one of the ancient cities of northern Ethiopia and regional capital city of Tigray regional state, situated about $780 \mathrm{~km}$ from Addis Ababa, near border of Ethiopia and Eretria at $39^{\circ}$ $25^{\prime} 21^{\prime \prime}$ 'to $39^{\circ} 33^{\prime} 35^{\prime \prime}$ 'E and $13^{0} 24^{\prime} 29^{\prime \prime}$ 'to $13^{\circ} 26^{\prime}$ 21 ' $\mathrm{N}$. The eastern side of the city is bounded by Enda-Eyesus ridges. Expansion of city touches the Block Mountain at north which is tilted with left bank of River Ellala. The relief of the city is young interior scarped plain (plateau) by elevation range 2000 to 2200 masl. Average annual temperature and rainfall of the city is $14^{\circ} \mathrm{C}$ to $34^{\circ} \mathrm{C}$ and $575-650 \mathrm{~mm}$ respectively (Tigray Regional Office, 2010).

Population of the city is 215,456 consisting 104,758 males and 110,788 females, residing in seven sub-cities namely Hawelti, Ayder, Adi-haki, Semien, Hadnet, Kedamey and Quiha (CSA, 2007). Growth of population is associated with rural to urban as well as cross-border migration (Dessalegn and Aklilu, 2003). Agro-processing, small and household level industries by formal and informal sectors, construction works and transactions of agricultural commodities, materials related to construction and basic infrastructure are sources of employment and livelihood occupations. Recently, the city has been popular for rapid development regarding education, political and economic aspects (Ali, 2013).

\section{Methodology}

The study is based on primary sources of the data gathered by field surveys in Feb-March 2012 through questionnaire/schedule focused on arrival distance, ethnicity, age, sex, marital life, education, income, and dwelling, sanitation facilities of the daily labourers.

On the basis of random sampling, out of seven, three sub-cities; Hawelti, Kedamay Weyane and Quiha (about $43 \%$ of the total) were selected. Following the purposive sampling, 120 respondents were interviewed randomly, 40 from each sub-city. The collected data were processed in tabular form and to derive specific conclusion, simple mean and percentage methods were used. The data were analyzed and represented through pie and bar diagrams.

\section{Results and Discussion \\ Religious Profile of Daily Labourers}

Religion is considered a strong aspect in the analysis of the socio-economic conditions of the daily informal construction labourers in Ethiopian society because religion has influence on working days and hours particularly urban areas of north Ethiopia (Caulk, 1981). Figure 3 shows that $78 \%$ daily labourers were Orthodox Christians followed by Muslims (19\%) and others (3\%) respectively. The Orthodox Christianity has been considered the way of life that shaped the society including needs, economic activities, working conditions in the study area since $4^{\text {th }}$ century. The share of followers of the Islam was 19\%, they have been integral part of the north Ethiopia since $7^{\text {th }}$ century with the first Islamic Hizarat (migration) to Nagash Kingdom of Abyssinia (50 km away from Mekelle) to follow the direction of Prophet Mohammad to save his followers from the Saudi Arabian prosecution (Carillet et al, 2009).

\section{Ethnic Profile of Daily Labourers}

In spite of Study area being capital city of Tigray region, there was demographic diversification among the daily construction labourers consisting with $66.67 \%$ share of Tigrarian ethnic labourers followed by Amhara $(20 \%)$ and Afar (13.33\%) respectively (Figure 4). It was recorded during field survey that the 
Amhara ethnic labourers arrived particularly from the north simian Gondar area consisting with remote hilly tracks adjacent of Tigray region. There is agriculture only means of livelihood but rapid soil erosion snatched the production capability of cultivation, as a result, a chunk of rural people permanently left their the native places and arrived migrated to Mekelle, and joined the daily labour profession. Besides, the Afar people were basically nomads came to deliver the salt in a small group or with the camel caravans. They spent time in the city and realized that survival of life is easy in comparison to their native places (Afar) where they lived nomadic life in high temperature, deficiency of rainfall and scarcity of fodders for animals (Englebert, 1970; Ali, 2012a) As the Afar people are considered fearless hard workers consequently, their demand is for daily labour profession.

\section{Travelling Profile of Daily Labourers}

Figure 5 shows that $83 \%$ daily construction labourers, travelled distance more or less $20 \mathrm{~km}$ to do labour for earning because rural hinterland of Mekelle soil has been eroded, and hilly terrains, poor soil moisture (deficient rainfall) support hardly one crop to cultivate in year. Moreover, due to deforestation as well as vegetation degradation, lumbering, charcoal and livestock husbandry lost the lucrative sources for livelihood. Contrary, development of physical infrastructure, i.e., buildings (residential colony), roads, streets, drains and so on have been pulled people from the $20 \mathrm{~km}$ distance at a good extent. However, existing unemployment, underemployment and homelessness conditions at local level, 27\% urbanities, some of them were graduate, joined as daily labourers at construction sites for earning. It was noted during field survey that some daily labourers were previously involved in pity trade at the footpath who shifted their profession due to hike prices, snatching the business points to arrange zones, sectors for the transaction of different commodities and city beautification.

Moreover, $17 \%$ daily construction labourers arrived more than $20 \mathrm{~km}$ where the scarcity of work and income sources due to the natural and anthropogenic factors were common that pushed rural population from a far distance including Amhara and Afar regions to search the opportunies for the survival and livelihood.
Consequently, they started work in the construction to earn the hard cash. It is considered a good option when labourers not having skillful for other occupations and kith and kin ship/trusty at a new place.

\section{Marital Profile of Daily Labourers}

It was recorded during field survey that $63.3 \%$ labourers were married followed by bachelors $(24.2 \%)$, widowers and those were living separated (12.5\%) respectively. Married life is necessary for a sound social acceptability (Waite and Gallagher, 2000) but after marriage if the sources of the income are not properly, then to bring up the family people join the work that could easily available.

\section{Profile of Daily Labourers by Age}

The work related to construction needs physical strength that grows naturally in an age limit biological process (Kail and Cavanaugh, 2004); such facts were recorded during field survey that the highest share (58.86\%) was working age of the daily construction labourers who involved in manual work from morning to till evening. Besides, about $38 \%$ of the daily labourer population belonged to below 14 years having higher proportion of females (Table 1). But after 14 years, mostly females were either marriages, or involved in the restaurants, hotels as workers, and started live separate; therefore, their share was lower at the age above 14 years. Moreover, the daily construction labourers are poor, unemployed and measurable dwellers so in many cases, they were not married due to enable to bear family expanses (Figure 6).

\section{Educational Profile of Daily Labourers}

Education is considered a key to expand the horizons of the minds and to develop thinking to live well social and economic life (UN, 2005; UNICEF, 2010). However, during field survey it was recorded that illiteracy and poor education was the common among the daily informal labourers those were engaged in construction works. Table 2 reflects that daily labourers were illiterate $(27.03 \%)$ and literate those can only read and write $(32.43 \%)$. Primary, secondary, $10+2$ and above educated were $24.02 \%, 10.81 \%$ and $5.71 \%$ respectively. Poor educational status is a reflection of their deprived conditions; they started to work for survival at early age, therefore, they could not get opportunities to get education (Charles, 2002). 
The status of education was more measurable among the females of daily labourers that their counterpart (Table 2).

\section{Occupational Profile of Daily Labourers}

The occupational profile of daily labourers highlights that not only heads of the household work entire day but their family members are also engaged in different occupations to earn money for the survival (Elliott and Kriuo, 1991). Table 3 shows that family members of the daily workers were mainly engaged as hotel/restaurant workers (33.48\%) followed by agricultural labourers (27.23\%), housemaids $(22.32 \%)$ and selling animal and agricultural commodities, i.e., eggs, milk, its products, small heap of vegetables, fruits and cereals $(16.96 \%)$ respectively. It was recorded during field survey that women were more active all above mentioned occupations except agricultural labourers.

\section{Income Profile of Daily Labourers}

Figure 6 depicts that $72.5 \%$ daily labourers earned their total income (including their family income) below $1200 \mathrm{birr} / \mathrm{month}$ followed by those were earning 1200-1800 and above 1800 birr per month respectively. The level of their lower income reveals that mostly daily construction labourers did not get continuous work for all days of the month. It was noted that there were 25 common working days among daily construction labourers, sometimes; they got work only 10-15 days in a month. However, due to unavailability of regular work and poor wages, workers and families both were engaged in different occupations, their income was more than 1200 birr/month.

\section{Profile of Dwelling Conditions of the Daily Labourers}

Dwelling is one of basic needs in order to survive the protected life in the urban areas (Ali, 2012a). Figure 7 depicts $45 \%$ daily labourers who engaged in construction activities were hut/ slum dwellers. They constructed their hut, using local products on the bare land of government or private sector for a time limit by the negotiation of their respective owners. However, at many places of the city, to spend the nights they built their residences along the drain, stream and on public land illegally.

There were $35 \%$ daily labourers passing their lives in houses consisting with lower quality constructed houses with stone (wild stone used for the construction of walls), cheap local wood and tin (used for roof). Moreover, the 20\% daily labourers lived in the rent houses. It was recorded during field investigation that such houses were equipped with few domestic possessions mainly related to kitchen.

\section{Profile of Basic Amenities and Facilities}

Table 4 shows that $60.83 \%$ daily labourers were users of spring or public taps water for drinking followed those having water taps in their premises (20\%), users of water from stream/pipe (16.83\%) respectively. The water is essential for any houses and its availability and use is considered an index for the quality life. The supply of drinking as well as daily use purposes was not properly among the household of the daily labourers, there was a lion share of them was dependent on the public taps and springs. The supply of water through public tap is always uncertain and unreliable, generally it is supplied three days in a week but the supply is usually in night sometimes mid night, even it may be before mid-night and very early morning. Since, the daily labourers as well as their family do physical hard works over the day so they need a rest at the nights but supply of water hardly allow them to sleep properly, there is necessary the vigilance on water otherwise they could not get sometimes a single drop of water at morning in the taps. It was reported during field survey that prevailing hard works in the day and restless nights weaken negatively effect on their health and performance of the work. Moreover, the supply of water is very uncertain and unreliable in the months of February to May particularly at outer of city where majority of the daily labourers reside. In such circumstances they fetch water from spring, stream and pipe to fulfil their needs.

It was noted during field survey that $82.5 \%$ households of daily labourers, travelled distance up to 500 metres to fetch water. Moreover, in remaining households, water was fetched from 500 to 1000 metres by the family members. They spent more than 2 hours to carry 20 litres jerry cane of the filled water. In these houses, one or ywo family members are on duty daily to fetch water the taps, spring and stream pipe or directly from the stream (Birhane, 2010). Toilet facilities are necessary for a civic society to biological cycle 
need (Ali, 2012). But, generally, such facilities were absence in $75.83 \%$ households of the daily labourers. Regarding the causes were investigated that the low income, poor type of dwelling, existing thought that toilet is not an essential so they finished their night soils anywhere even without water. Moreover, unreliable water supply, limited earning and time to expanse on body and cloth wash; there was occasionally bathing in practice of the daily labourers. However, among the $17.5 \%$ households were with traditional toilets (open without walls), as well as only $6.67 \%$ was consisted toilets with seat and side walls. There were total family earning and educational of households of the daily labourers was comparatively higher, therefore, they constructed toilets regarding consciousness for health and sanitation.

\section{Conclusion}

The analysis of socio-economic conditions of daily construction labourers reveals that their majority was devotee of Orthodox Christianity followed by Muslims. Tigrian ethnicity was common their recognition. Mainstream of them travelled $20 \mathrm{~km}$, and farther distance to arrive the city for the work. Prevailing unemployment, backward agriculture, sloppy terrain, unfertile and degraded soil at their native places pushed them to join physical labour in the construction which has not more requirement of skill and easily available in Mekelle. The lion share of daily labourers spent married life with family; followed by single and widower/separate categories. Their dominated age group was 14-44 years because body strength is the basic requirement to do bulky and hard work. However, females were more till 14 years age in daily labourers' family, but later they either married at other places/status of the society, or moved to do work in hotels and restaurants to live separately from their parents. The poor status of education was common phenomena among daily labourers. A chunk of their population was either illiterate, or having only knowledge to read and write. However, due to lack of employment, urban youths joined this profession, despite having senior secondary and above qualification. Instead of the daily labourers, members of their family worked as housemaids, farm labourers, restaurant workers, as well as selling of small agro/animal products to earn money for their survival. In spite of such hard efforts, 2/3 population of daily labourers earned less than 1200 birr per month. The reflection of incapability of earning from their profession was visible among their residential lives and housing conditions. Majority of them lived in hut, slum, and locally built houses having deprived basic amenities and facilities, i.e., drinking water and toilet facilities.

\section{Acknowledgments}

Author is grateful to Mr. Bezu Ababe, graduate student, department of geography and environmental studies and Mr. Mahfuz Mohammad, graduate student, department of business and management, Mekelle University, Ethiopia for the help during field surveys.

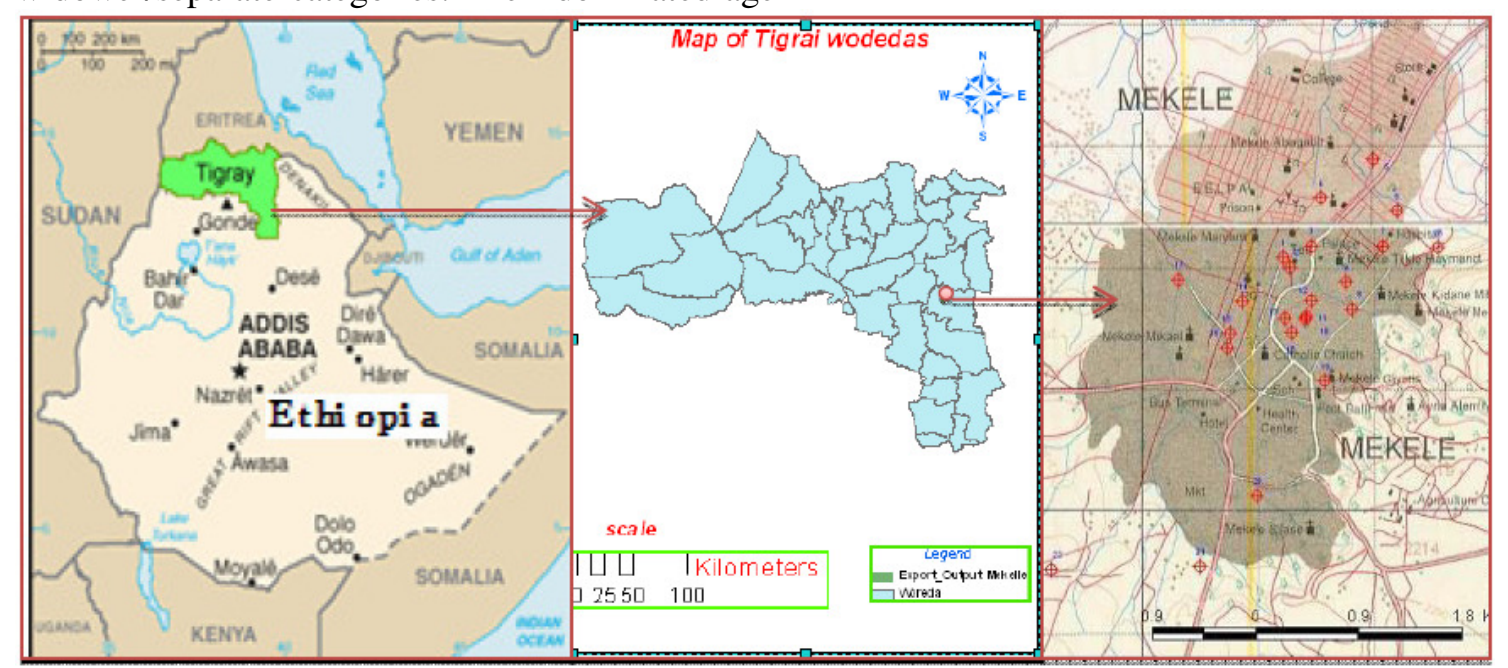

Figure 1: Location map of the Study Area 


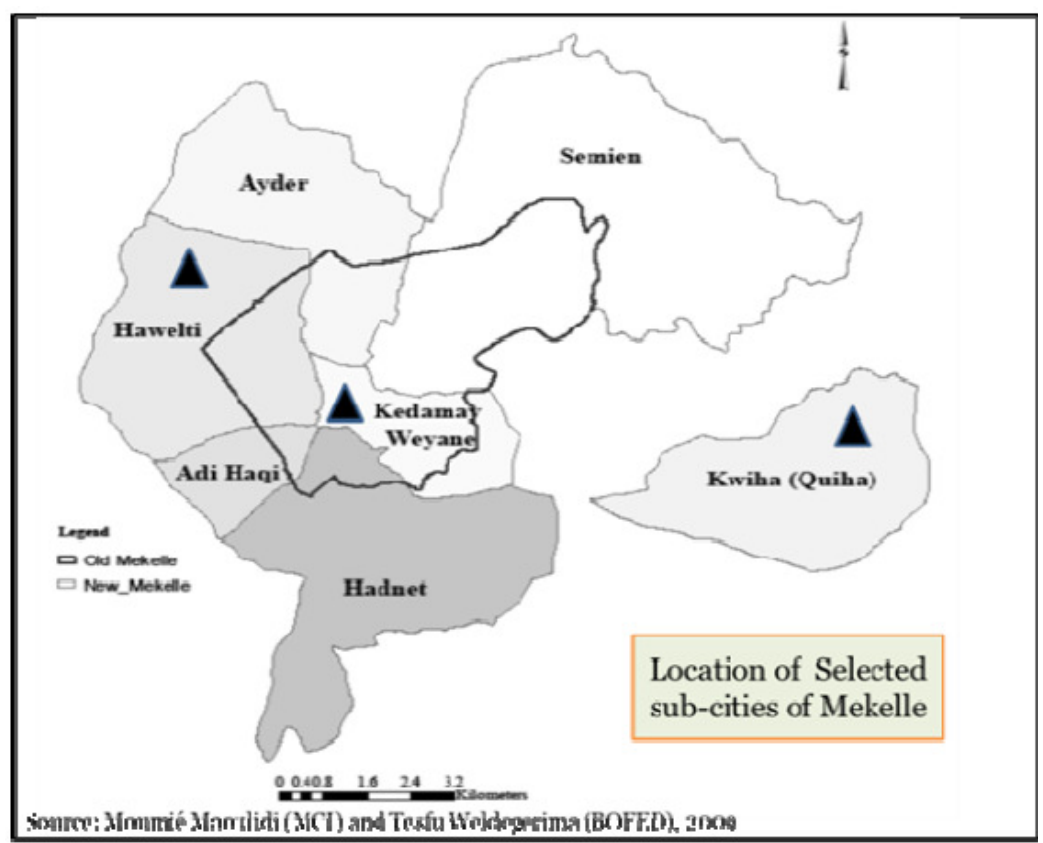

Figure 2: Location of selected sub-cities

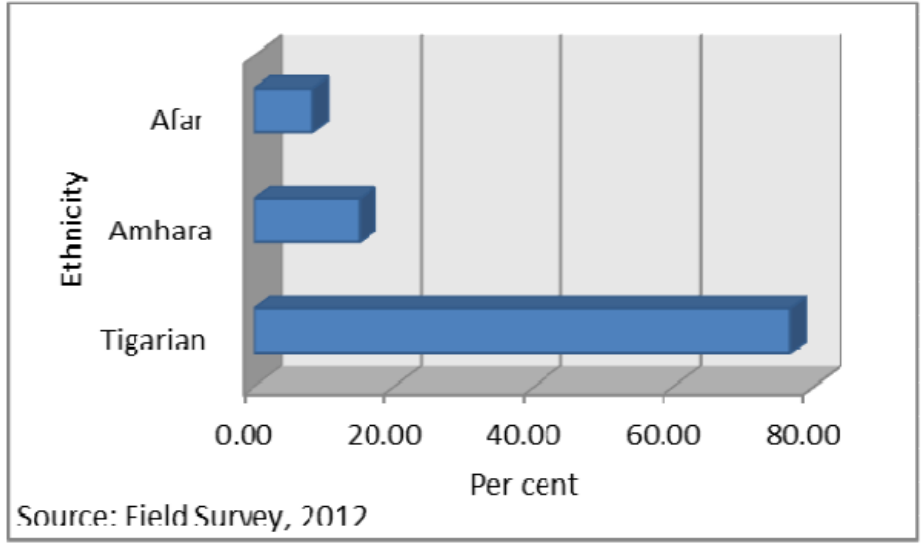

Figure 3: Daily labourers by religion

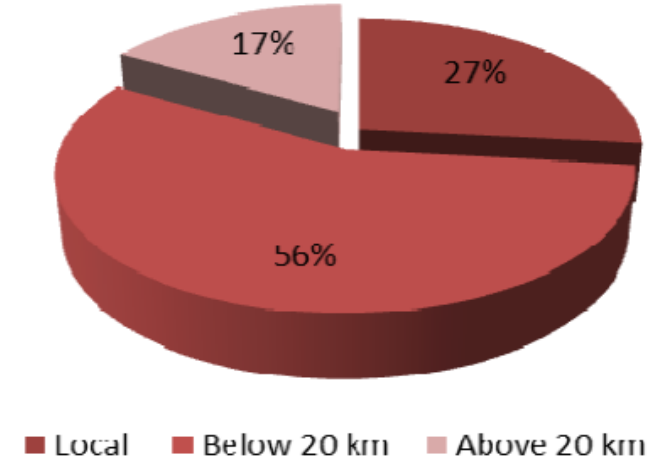

Figure 4: Ethnic profile of daily construction labourers 


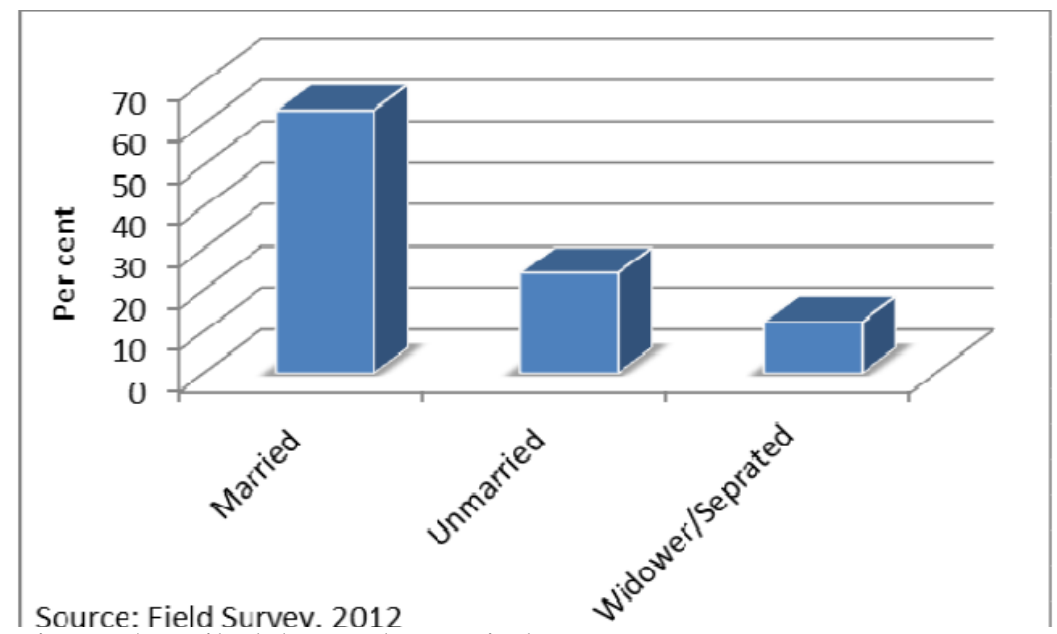

Figure 5: Daily laborers by marital status

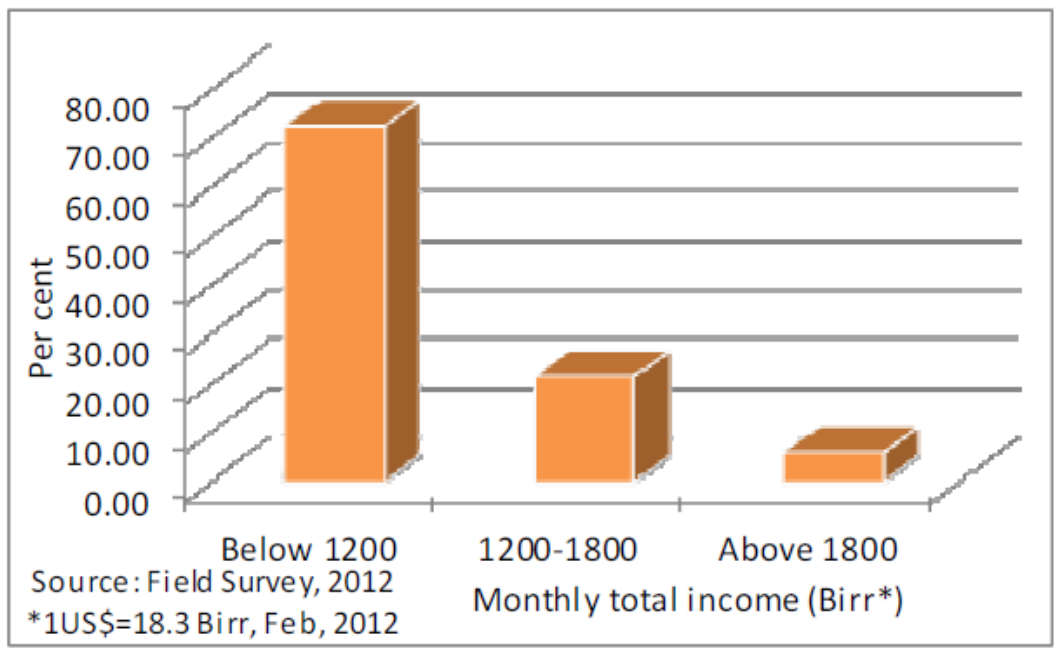

Figure 6: Daily labourers by income

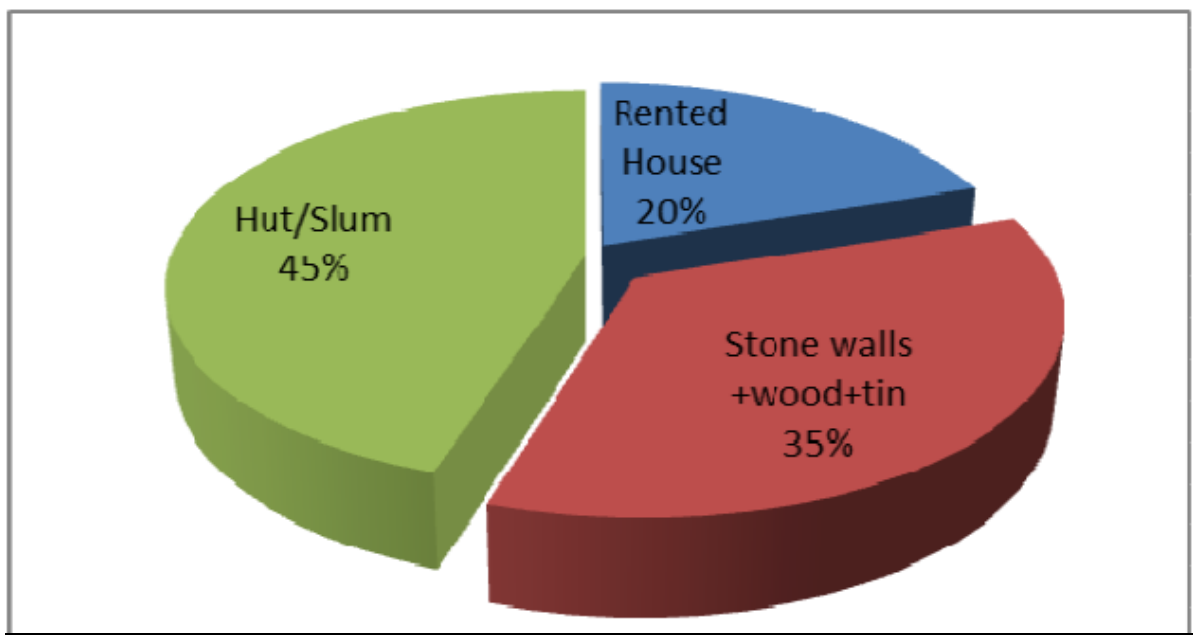

Figure 7 Daily labourers by type of dwellings 
Table 1 Daily labourers by age group

\begin{tabular}{llll}
\hline Age group (yrs.) & Male $(\%)$ & Female $(\%)$ & Total $(\%)$ \\
\hline Below 6 & 15.38 & 19.87 & 17.42 \\
$6-14$ & 18.13 & 23.84 & 20.72 \\
14-44 & 46.70 & 33.77 & 40.84 \\
44-60 & 18.13 & 17.88 & 18.02 \\
Above 60 & 1.65 & 4.64 & 3.00 \\
\hline$* \mathrm{~N}=333$ & & &
\end{tabular}

Table 2 Daily labourers by educational status

\begin{tabular}{llll}
\hline Education level & Male $(\%)$ & Female $(\%)$ & Total $(\%)$ \\
\hline Illiterate & 29.81 & 22.40 & 27.03 \\
Literate & 29.81 & 36.80 & 32.43 \\
Primary & 21.15 & 28.80 & 24.02 \\
Secondary & 13.46 & 6.40 & 10.81 \\
$10+2$ and Above & 5.77 & 5.60 & 5.71 \\
\hline
\end{tabular}

$* \mathrm{~N}=333$

Table 3 Daily labourers by type of occupations

\begin{tabular}{llll}
\hline Type of works & Male $(\%)$ & Female $(\%)$ & Total $(\%)$ \\
\hline Housemaids & 15.58 & 25.85 & 22.32 \\
Agricultural labourers & 41.56 & 19.73 & 27.23 \\
Hotel/restaurant workers & 28.57 & 36.05 & 33.48 \\
$\begin{array}{l}\text { Selling-agri/products } \\
\text { products }\end{array}$ & 14.29 & 18.37 & 16.96 \\
\hline
\end{tabular}

$* \mathrm{~N}=224$

Table 4 Daily labourers by basic amenities and facilities

\begin{tabular}{|c|c|c|}
\hline 1. & Drinking water & $(\%)$ \\
\hline \multirow{8}{*}{2.} & Taps/spring & 60.83 \\
\hline & Stream/pipe from spring & 19.17 \\
\hline & Taps with in premises & 20.00 \\
\hline & Total & 100.00 \\
\hline & Distance of the source of drinking water & $(\%)$ \\
\hline & up to $500 \mathrm{~m}$ & 82.50 \\
\hline & 501 to $1000 \mathrm{~m}$ & 17.50 \\
\hline & Total & 100.00 \\
\hline \multirow[t]{5}{*}{3.} & Type of toilet (latrine) & $(\%)$ \\
\hline & -Traditional & 17.50 \\
\hline & -Seat with side walls & 6.67 \\
\hline & -No toilet & 75.83 \\
\hline & Total & 100.00 \\
\hline
\end{tabular}

\section{References}

Ali, M. (2012). "Socio-Economic Analysis of Poorest of the Poor Section-Beggars in Urban and its Peri-Areas: A Case study". presented at International Conference on Culture, Environment and Development, Ethiopia: Mekelle University, March 15
Ali, M. (2012a). "Socio-Economic Analysis of Homeless Population in Urban Areas: A Case Study of Ethiopia, International Journal of Scientific and Research Publications, 2(8):1-8.

Ali, M. (2013). "Status of Informal Work Force in Urban Masses: a Case Study of Northern 
Ethiopia”. International Journal of Scientific Research, 2(3): 192-98.

Birhane, K. (2010). "Water Supply and Factors Affecting Consumption Level: The Case of Mekelle Town". Tigray Region, Unpublished thesis, Addis Ababa University, Ethiopia.

Bitran, J. (2005). "Keeping Health in an Urban Environment: Public Health Challenges for the Urban Poor". In The Urban Poor in Latin America." edited by M. Fay, The World Bank, Washington, DC: 179-194.

Brixiova, Z. (2010)."Unlocking Productive Entrepreneurship in Africa's Least Developed Countries." African Development Review, 22(3): 440-451.

Carillet, J.B., Butler, S. and Starnes, D. (2009). Ethiopia and Eritrea, 4th ed., Lonely Planet, London.

Caulk, R.H. (1981). "Islam and Christianity in Northeast Africa until 1500," Cambridge Encyclopedia of Africa: 117-124.

Charles, E. (2002). "Social in equality forms causes in side straight edge." National Geographic Society, 9 April.

Chen, M.A. and Lund, F. (2001). "Supporting Workers in the Informal Economy: a Policy Framework." ILO Task Force on the Informal Economy.

CSA (2006). "Report on National Labour Force Survey". The Federal Democratic Republic of Ethiopia, Central Statistical Agency, Addis Ababa, Statistical Bulletin, 365.

CSA (2007). Population Dynamics, Central Statistical Agency, Addis Ababa

Dessalegn, R. and Aklilu, K. (2003). "Vulnerable Livelihoods: People's Security Survey of Urban Households in Ethiopia, Addis Ababa". Forum for Social Studies and MizHasab Research Center, Ethiopia.

EEA (2003). Ethiopian Economic Association. Economic Focus, 5: 3 \& 4.

Englebert, V. (1970). The Dankali Nomads of Ethiopia's Wasteland, National Geographic Index 1988-1998, Vol. 174(3), Sept, 1998
Elliott, J. and Kriuo, T. (1991). "Characteristics of Transitional Housing for Homeless Families." Final Report, Urban Institute, Washington, DC.

Kail, R.V. and Cavanaugh, J. C. (2004). "Human Development: A life-span View" (3rd ed.). Thomson/Wadsworth, Belmont, CA: 16.

Lewis, W. A. (1954). "Economic Development with Unlimited Supplies of Labour." Manchester School, 139, 22 May.

National Research Council (2003). "Cities Transformed: Demographic Change and its Implications in the Developing World." edited by Panel on Urban Population Dynamics et al., National Academies Press, Washington, DC.

Peter, M. and Lamin, B. (2010). "Ethiopia's Economic growth Performance, Current Situation and Challenges." Economic Brief, 5(1): 17 .

Satterthwaite, D. (2004). "The Under-Estimation of Urban Poverty in Low and MiddleIncome Nations." IIED, London.

Tigray Regional Office (2010). Mekelle Town Information, Mekelle, Ethiopia

UN (2005). "Department of Economic and Social Affairs Statistics Division, Demographic and Social Statistics Branch", United Nations

Waite, L. and Gallagher, M. (2000). The Case for Marriage, Doubleday, New York.

Woolcock, M., (1998). "Social Capital and Economic Development: towards a Theoretical Synthesis and Policy Framework." Theory and Science, 27: 151208.

Sverdlik, A. (2011). "Ill-Health and Poverty: A Literature Review on Health in Informal Settlements." Environment and Urbanization, 23 (1): 126.

UNICEF (2010). "Understanding Urban Inequalities in Bangladesh: A Prerequisite for Achieving Vision 2021-A study based on the results of the 2009 Multiple Indicator Cluster Survey."www.unicef.org/bangladesh/Urban_ paperlowres.pdf (accessed 25 September 2011). 